\title{
Landscape of interventional clinical trials involving gastrectomy for gastric cancer
}

\author{
Hussein H Khachfe ${ }^{1,2,3}$, Hamza A Salhab ${ }^{1,4}$, Mohamad Y Fares ${ }^{1,4}$, Mohamad A Chahrour ${ }^{1}$ and Faek R Jamali ${ }^{5}$ \\ ${ }^{1}$ Faculty of Medicine, American University of Beirut Medical Center, Beirut 00000, Lebanon \\ ${ }^{2}$ Department of Surgery, University of Pittsburgh Medical Center, Pittsburgh, PA 15260, USA \\ ${ }^{3}$ Division of GI Surgical Oncology, UPMC Pancreatic Cancer Center, University of Pittsburgh Medical Center, UPMC Cancer Pavilion, Pittsburgh, PA 15260, USA \\ ${ }^{4}$ Neuroscience Research Center, Faculty of Medical Sciences, Lebanese University, Beirut 00000, Lebanon \\ ${ }^{5}$ Division of General Surgery, Department of Surgery, Sheikh Shakhbout Medical City, Abu Dhabi 11001, UAE
}

\section{Abstract}

Background: Gastric cancer (GC) is the third most common cause of malignancy associated mortality globally. The cornerstone of curative treatment involves surgical gastrectomy. In this study, we explore clinical trials involving gastrectomy for GC, highlighting inadequacies and underlining promising surgical interventions and strategies.

Materials and methods: On 1 May 2020, ClinicalTrials.gov was explored for interventional trials related to gastrectomy for GC, without adding limitations for location or date. All data pertaining to the trials were collected. Characteristics such as phase, duration, enrolment size, location, treatment allocation, masking and primary endpoint were analysed.

Results: One hundred thirty-eight clinical trials met the search criteria. Clinical trials were performed in only 14 countries; most of them occurring in China. Most trials (33\%) were still in the recruiting phase. On average, the length of trials was 3.9 years. Most trials had parallel assignment, were randomised and masked. The primary endpoint which was mostly commonly studied was overall survival (33\%). The most common intervention studied is laparoscopic gastrectomy in 43 (31\%) trials.

Conclusions: Our study exposed a small number of trials, publication rate, absence of geographic variety in clinical trials involving gastrectomy for GC. Adequate management of trial design can help decrease duration and increase validity of results. More trials comparing different surgical techniques are needed to update the surgical practice of gastrectomy for GC.

Keywords: stomach, gastric cancer, gastrectomy, general surgery, clinical trials

\section{Introduction}

Among all causes of death worldwide, cancers and malignancies are the second most common cause [1]. The six most prevalent cancer globally and third common cause of malignancy related mortality is gastric cancer (GC) [2]. The majority (almost 90\%) of GCs are adenocarcinomas, which arise from mucosal glands of the stomach [3]. GC incidence

Correspondence to: Hussein $\mathrm{H}$ Khachfe Email: hhk15@mail.aub.edu

ecancer 2021, 15:1218

https://doi.org/10.3332/ecancer.2021.1218

Published: 08/04/2021

Received: 24/11/2020

Publication costs for this article were supported by ecancer (UK Charity number 1176307).

Copyright: (c) the authors; licensee ecancermedicalscience. This is an Open Access article distributed under the terms of the Creative Commons Attribution License (http:// creativecommons.org/licenses/by/3.0), which permits unrestricted use, distribution, and reproduction in any medium, provided the original work is properly cited. 
rates vary extensively between both sexes, and across different countries and geographic locations [3]. The areas with the highest rates of GC worldwide are East Asia and Eastern Europe, while North America is home to the lowest rates in the world [4].

The cornerstone of curative treatment for this disease is surgical resection with lymphadenectomy [5]. Yet, only about 50\% of all GC patients may undergo resection with curative intent. Curative resection has a '5-year survival rate' of around $45 \%$, with perioperative chemotherapy improving that rate by around $10 \%[6,7]$.

In the past couple of decades, surgeries for GC have witnessed a shift from the traditional open approach to more minimally invasive operations [8]. These new techniques include laparoscopic assisted, total laparoscopic, robot assisted and total robotic operations. Now, minimally invasive surgical approaches have become the new standard for GC. These surgeries provide briefer hospital stay, faster recovery and general enhancement in patient quality of life $[9,10]$. This shift to minimally invasive surgeries came about because of reasons such as advancements in surgical instruments, increased experience among surgeons and the better outcomes associated with them [11].

In recent years, surgery has become the primary intervention employed in the management of GC. Beneficial clinical outcomes depend heavily on finding of new surgical techniques and treatment plans. Therefore, it is vital to evaluate surgical interventions that are currently in trial or new ones that have arose. Here, we give an overview of gastrectomy clinical trials for GC, study the characteristics, discuss the inadequacies associated with them, highlight the effective interventions present and suggest potential rooms for enhancement.

\section{Materials and methods}

\section{Search strategy and selection criteria}

On 1 May 2020, we retrieved all information on clinical trials involving gastrectomy for GC from ClinicalTrials.gov. This search was conducted without adding limitations for date or location. 'Clinicaltrials.gov' is a registry that archives new data on various clinical trials weekly. For investigators to submit entries into the registry, they are required to provide extensive specifics on their particular trial. These details include trial profile, a report of protocol used in their study and any history that may be relevant. Analysis and extrapolation of conclusions on the basis of information present in this wide-ranging registry has previously been described in a number studies [12, 13].

Of the 326 total trails collected, 177 were eliminated as they were either 'non-interventional' or did not involve gastrectomy as an intervention. This exclusion was done using a parallel elimination plan as Nasrallah et al [14] where withdrawn/terminated and 'non-interventional' trials were not included in the final set of studies analysed (Figure 1).

\section{Data collection}

All information relating to the clinical trials were gathered. This included: trial status ('active not recruiting', 'completed', 'enrolling by invitation', 'not yet recruiting', 'suspended', etc.), phase of trial ('I', 'I/II', 'II', 'II/III', 'IV'), the official start and end/completion dates, location (city/ country), selection criteria (inclusion and exclusion), primary endpoints, sample size, outcomes, interventions used and where any publications were produced. Trial duration was calculated from the official start date until the primary end/completion date. This was done to be in accordance to the Food and Drug Administration Amendments Act which was announced in 2007 (Section 801) [15]. Primary endpoints were defined as '30-day reoperation', 'number of lymph nodes harvested/collected', 'operation time', 'percentage body weight ratio', 'overall survival', 'postoperative length of stay', 'postoperative morbidity', 'postoperative outcomes', 'progression-free survival', 'rate of conversion', 'quality of life', 'time till drain removal' and 'tumour recurrence rate'.

\section{Publications produced}

Articles or published manuscripts originating from trials were retrieved using the ClinicalTrials.gov identification number (NCTID) of each respective clinical trial. NCTID numbers were inserted into several search engines. The most important of which were 'PubMed/Medline' and 'Scopus/Embase'. This was done to find the related published works present (if any was to be found). Should a clinical trial have had a 
linked published work, then the NCTID number would be included in the original publication, and the work would subsequently appear in the search. Retrieved articles/published manuscripts were gathered and subsequently reviewed by two independent authors/investigators to recognise which ones were reporting primary outcomes/results.

\section{Ethical approval}

This study did not require/need any ethical approval of informed consent due to its epidemiologic nature (de-identified, publicly accessible data).

\section{Results}

\section{Trial characteristics}

One hundred and thirty eight trials had the criteria needed of our study. The distribution of these clinical trials was done according to characteristic details such as the number of participants, phase, status, location and duration in Table 1. This study showed that 39,954 participants were registered altogether in clinical trials involving gastrectomy for GC (Table 1). More than $70 \%$ of trials had $>100$ patients enrolled (Table 1). Clinical trials were performed across only 14 different countries, with the majority taking place in Asia/Australia (Table 1, Figure 2). The duration/length was stated in all trials, with an average length of 3.9 years (Table 1). Most trials (33\%) were in the recruiting phase. Almost all (95\%) of the clinical trials were for adults only, and all of them (100\%) were for both genders.

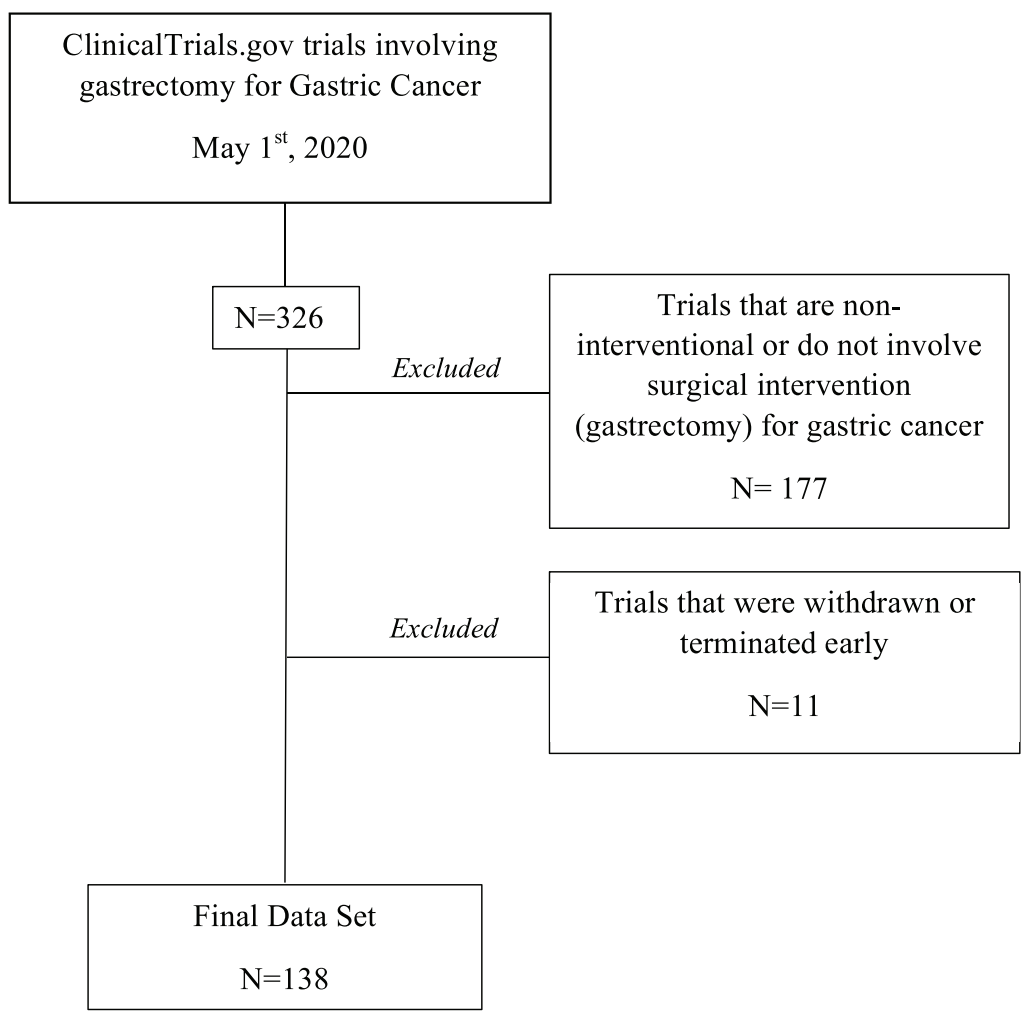

Figure 1. Clinical trial selection process for trials involving gastrectomy for GC from ClinicalTrials.gov. 
Table 1. Characteristics of trials involving gastrectomy for GC as found on ClinicalTrials.gov as of 1 May 2020.

\begin{tabular}{|c|c|c|c|c|c|c|c|c|}
\hline & NA & Phase I & Phase I/II & Phase II & Phase II/III & Phase III & Phase IV & Total (\%) \\
\hline Number of trials & 62 & 2 & 3 & 26 & 3 & 41 & 1 & 138 (100\%) \\
\hline \multicolumn{9}{|l|}{ Trial status } \\
\hline Active, not recruiting & 6 & - & - & 2 & - & 1 & - & $9(7 \%)$ \\
\hline Completed & 14 & - & 3 & 5 & - & 11 & - & $33(24 \%)$ \\
\hline Enrolling by invitation & 4 & - & - & 1 & - & 1 & - & $6(4 \%)$ \\
\hline Not yet recruiting & 4 & - & - & - & - & 2 & - & $6(4 \%)$ \\
\hline Recruiting & 23 & - & - & 7 & 2 & 14 & - & $46(33 \%)$ \\
\hline Unknown status & 11 & 2 & - & 11 & 1 & 12 & 1 & $38(28 \%)$ \\
\hline \multicolumn{9}{|l|}{ Estimated enrolment } \\
\hline $0-10$ & 1 & - & - & - & - & - & - & $1(1 \%)$ \\
\hline $11-50$ & 9 & - & 2 & 4 & - & 3 & - & $18(13 \%)$ \\
\hline $51-100$ & 8 & 1 & 1 & 6 & - & 2 & - & $18(13 \%)$ \\
\hline$>100$ & 44 & 1 & - & 16 & 3 & 36 & 1 & $101(73 \%)$ \\
\hline Results present & - & - & - & 1 & - & - & - & $1(1 \%)$ \\
\hline Publication & 16 & 1 & 2 & 10 & - & 26 & 2 & 57 (41\%) \\
\hline \multicolumn{9}{|l|}{ Age group } \\
\hline Adult only & 55 & 2 & 3 & 26 & 3 & 41 & 1 & $131(95 \%)$ \\
\hline Adult and paediatric & 7 & - & - & - & - & - & - & $7(5 \%)$ \\
\hline Paediatric only & - & - & - & - & - & - & - & 0 \\
\hline \multicolumn{9}{|l|}{ Gender } \\
\hline Both & 62 & 2 & 3 & 26 & 3 & 41 & 1 & $138(100 \%)$ \\
\hline Male & - & - & - & - & - & - & - & 0 \\
\hline Female & - & - & - & - & - & - & - & 0 \\
\hline \multicolumn{9}{|l|}{ Trial location } \\
\hline Americas & 1 & - & - & 2 & - & - & - & $3(2 \%)$ \\
\hline Europe/UK/Russia & 7 & - & - & 2 & - & 5 & 1 & 15 (11\%) \\
\hline Asia/Australia & 52 & 2 & 3 & 22 & 3 & 36 & - & $118(86 \%)$ \\
\hline Africa & 2 & - & - & - & - & - & - & $2(1 \%)$ \\
\hline \multicolumn{9}{|l|}{ Trial duration (years) } \\
\hline$<1$ & 3 & - & 2 & 4 & - & 1 & - & $10(7 \%)$ \\
\hline $1-5$ & 50 & 2 & 1 & 21 & 2 & 24 & 1 & 101 (73\%) \\
\hline $5-10$ & 9 & - & - & 1 & 1 & 12 & - & $23(17 \%)$ \\
\hline $10+$ & - & - & - & - & - & 4 & - & $4(3 \%)$ \\
\hline
\end{tabular}

Trials were further assorted by interventional model, treatment allocation, masking and primary end point as in Table 2. In terms of interventional models, $82 \%$ of trials had parallel assignment (Table 2). 78\% of trials were randomised and were not masked (Table 2). The most common primary endpoint was progression-free survival, where it was present in $28 \%$ of all trials in our study. 


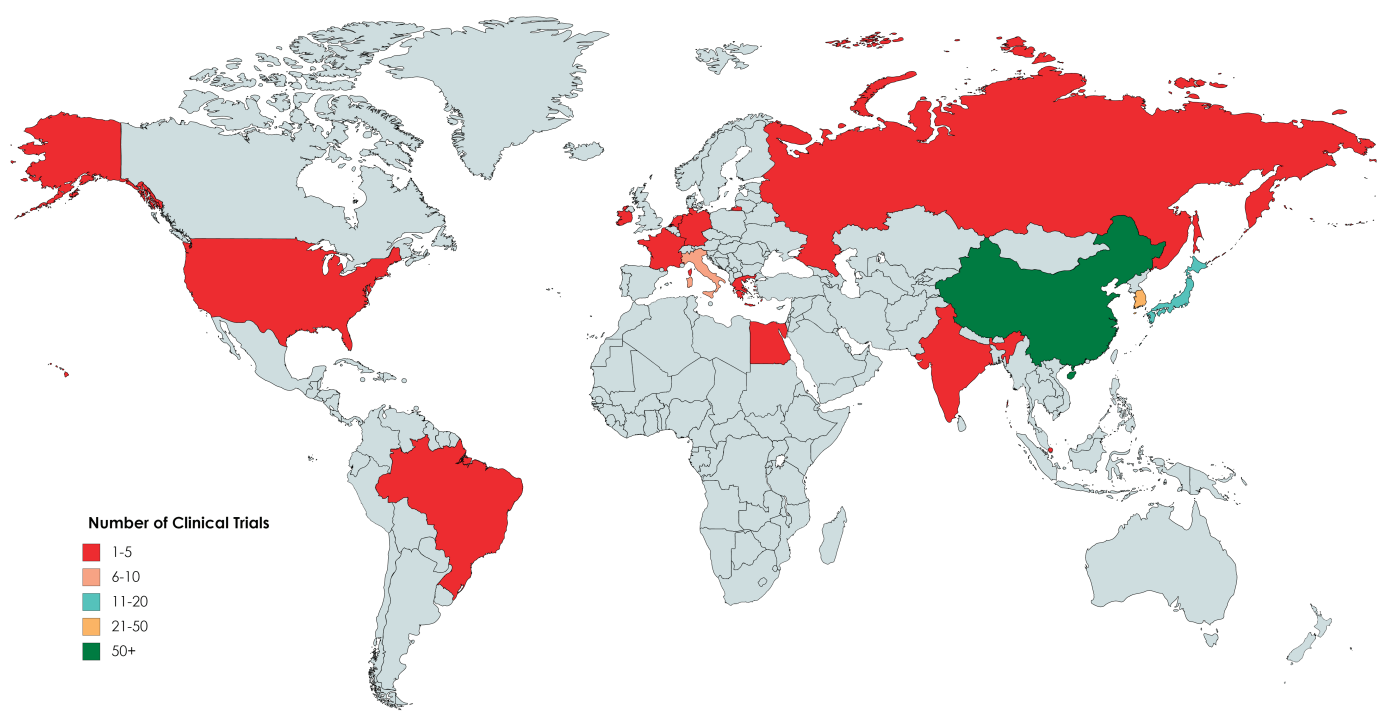

Figure 2. Distribution of clinical trials involving gastrectomy for GC according to ClinicalTrials.gov as of 1 May 2020.

\section{Publications linked to trials}

Of the 138 total clinical trials in our study, only 39 had linked publications related to gastrectomy surgeries for GC. A total number of 57 publications were retrieved (Table 1). Of the 33 completed trials, 28 publications were produced.

\section{Not applicable (NA)}

Sixty-two trials (45\%) were in this phase, with only 14 trials being completed (Table 1). Patients enrolled in non-applicable phase trials were 17,444. All four trials which included paediatric cases were found in this category (Table 1). These trials were spread across 12 different countries, with China conducting the highest number at 39 (63\%). Average trial duration in this phase was 3.3 years. Sixteen publications were linked to trials in this status (Table 1). The overwhelming majority of trials had parallel assignment (86\%), were randomised (79\%) and were not masked (67\%) (Table 2). Progression-free survival was the most common primary endpoint in these trials with a total number of 17 (28\%).

\section{Phase I trials}

Only 2 (1\%) trials were in phase I, both of which were of unknown status (Table 1). Phase I trials had 204 patients enrolled, both of which were only for adults. These trials were conducted in China and Republic of Korea (Table 1, Figure 2). Average trial length was around 3.5 years. A single publication was linked to these trials (Table 1). Both clinical trials were randomised, had parallel assignment and masked (Table 2). One trial focused on progression-free survival, while the other had a primary endpoint of quality of life (Table 2).

\section{Phase I/II trials}

Only 3 (2\%) trials were in Phase I/II, all of which were completed (Table 1). Phase I/II trials had 117 patients enrolled, all of which were only for adults. Two trials were conducted in Republic of Korea and one was done in China (Table 1, Figure 2). Average trial length was 1.8 years. Two published works were retrieved from phase I/II trials (Table 1). Single group assignment was found in two trials, while one trial had parallel 
assignment (Table 2). Two trials had no specified treatment allocation, while one trial was randomised. Two trials were not masked, while one trial did not specify any details on masking. The primary endpoints studied were: 'number of harvested/collected lymph nodes', 'postoperative morbidity' and 'rate of conversion' (Table 2).

\section{Phase II trials}

Twenty-six (19\%) trials were in phase II, only five of which were completed (Table 1). Trials of this status had 2,967 patients enrolled, all of which were adults only. Trials were distributed to six countries, with China conducting the highest number at 16 (Table 1 , Figure 2). Average trial length was 2.9 years. Ten published works were retrieved from trials in this phase (Table 1 ). The majority of trials (54\%) had parallel assignment and were randomised (Table 2). Almost all (92\%) of trials had no masking (Table 2). Progression-free survival was the most common primary endpoint, which was found in seven trials (Table 2).

Table 2. Study design and primary endpoints of clinical trials involving gastrectomy for GC as found on ClinicalTrials.gov as of 1 May 2020.

\begin{tabular}{|c|c|c|c|c|c|c|c|c|}
\hline & NA & Phase I & Phase I/II & Phase II & Phase II/III & Phase III & Phase IV & Total (\%) \\
\hline \multicolumn{9}{|l|}{ Interventional mode } \\
\hline Single group assignment & 10 & - & 2 & 12 & - & 1 & - & 25 (18\%) \\
\hline Parallel assignment & 52 & 2 & 1 & 14 & 3 & 40 & 1 & $113(82 \%)$ \\
\hline \multicolumn{9}{|l|}{ Treatment allocation } \\
\hline Nonrandomised & 6 & - & - & - & 1 & 1 & - & $8(6 \%)$ \\
\hline Randomised & 49 & 2 & 1 & 14 & 2 & 39 & 1 & 108 (78\%) \\
\hline Not specified & 7 & - & 2 & 12 & - & 1 & - & 22 (16\%) \\
\hline \multicolumn{9}{|l|}{ Masking } \\
\hline Open label (none) & 42 & - & 2 & 24 & 3 & 36 & - & 107 (78\%) \\
\hline Masked & 20 & 2 & - & 2 & - & 5 & 1 & $30(22 \%)$ \\
\hline Not specified & - & - & 1 & - & - & - & - & $1(1 \%)$ \\
\hline \multicolumn{9}{|l|}{ Main primary endpoint } \\
\hline 30-day reoperation & 1 & - & - & - & - & - & - & $1(1 \%)$ \\
\hline Number of harvested lymph nodes & 5 & - & 1 & 5 & - & 3 & - & $14(10 \%)$ \\
\hline Operation time & 4 & - & - & 1 & - & 1 & - & $6(4 \%)$ \\
\hline Overall survival & 4 & - & - & 4 & 2 & 15 & - & $25(18 \%)$ \\
\hline Percentage body weight ratio & - & - & - & - & - & 1 & - & $1(1 \%)$ \\
\hline Postoperative length of stay & 3 & - & - & 1 & - & 1 & - & $5(4 \%)$ \\
\hline Postoperative morbidity & 6 & - & 1 & 2 & - & 2 & - & $11(8 \%)$ \\
\hline Postoperative outcomes & 16 & - & - & 5 & - & 3 & 1 & $25(18 \%)$ \\
\hline Progression-free survival & 17 & 1 & - & 7 & 1 & 12 & - & $38(28 \%)$ \\
\hline Quality of life & 3 & 1 & - & 1 & - & 3 & - & $8(6 \%)$ \\
\hline Rate of conversion & - & - & 1 & - & - & - & - & $1(1 \%)$ \\
\hline Time to drain removal & 1 & - & - & - & - & - & - & $1(1 \%)$ \\
\hline Tumour recurrence rate & 2 & - & - & - & - & - & - & $2(1 \%)$ \\
\hline
\end{tabular}




\section{Phase II/III trials}

Three (2\%) trials were in phase II/III, only one of which was completed (Table 1). Trials of this status had 440 patients enrolled, all of which were adults only. All trials were conducted in China (Table 1, Figure 2). Average trial length was 4.6 years. No published works were retrieved from trials in this phase. All clinical trials had parallel assignment and were masked (Table 2). Two trials were randomised, while one was nonrandomised (Table 2). Two studies had a primary endpoint of overall survival, while one was interested in progression-free survival (Table 2).

\section{Phase III trials}

Forty-one trials (30\%) were in phase III, where 11 were completed (Table 1). Trials in this phase had 18,632 patients enrolled, all of which were adults only (Table 1). Trials were distributed to seven countries, where China had the highest number with 16 (Table 1 , Figure 2 ). Average trial length was 5.4 years. Twenty-six publications were linked to trials in this phase (Table 1). Almost all (98\%) trials had parallel assignment (Table 2), and the majority were randomised (95\%) and had no masking (88\%) (Table 2). The most common primary endpoint was overall survival (37\%) (Table 2).

\section{Phase IV trials}

A single (1\%) trial was in phase IV, and it has an unknown status (Table 1). The trial in this phase had 150 patients enrolled, where it was for adults only. The trial was conducted in Italy (Table 1, Figure 2). Trial length was 2 years. Two publications were linked to this trial (Table 1). The trial had parallel assignment, was randomised and non-masked (Table 2). The primary endpoint was postoperative outcomes (Table 2).

\section{Treated topics and current research lines}

The most commonly treated subtype of GC was unspecified in 78 (57\%) of trials (Tables 3 and 4). This was followed by advanced GC in 47 (34\%), and early GC in 13 (9\%). In terms of interventions used, laparoscopic gastrectomy was most commonly studied in 43 (31\%) trials (Table 3). This was followed by hyperthermic intraperitoneal chemotherapy (HIPEC) in 19 trials (14\%) and robotic gastrectomy in 16 (12\%) trials (Table 3).

\section{Discussion}

\section{Inadequacies of clinical trials}

As of May 2020, there have been 138 interventional clinical trials involving gastrectomy for GC. Surgical clinical trials for GC are rare. Of the 2,028 listed trials for GC, only 138 had experimental interventions involving gastrectomy, constituting $6.8 \%$ of the total number of trials. This low percentage and number may be accredited to several reasons.

Results from our study show that clinical trials involving gastrectomy for GC lack diversity, and that there is somewhat of a proportionality between disease burden and number of trials conducted. The overwhelming majority of trials were found in eastern Asia, which is also the most heavily burdened region in the world by the malignancy [4].

Our data shows that clinicals trials were conducted across only 14 different countries worldwide. Brazil was the only country in South America to have conducted a clinical trial on gastrectomy for GC and only Egypt had conducted a couple trials in the whole of Africa. This observation can be explained by several reasons. First, states present in less developed areas like Africa perhaps lack fiscal means and the 
set-up needed for research studies [16]. Globally, a great discrepancy is present in the prevalence and incidence of GC. For example, yearly age standardised incidence rates of GC in the Republic of Korea is 65.9 cases per 100,000 versus a mere 7.8 cases per 100,000 in the United States [17]. This can be explained by the notion that research on specific diseases is dependent on the burden of the disease itself. Furthermore, in a large number of countries, trials do not need to be registered in 'ClinicalTrials.gov'. This could explain why no studies were found in many nations around the world.

Table 3. Distribution of treated topics and interventions used in clinical trials involving GC.

\begin{tabular}{|c|c|}
\hline Treated topic & Number of trials (\%) \\
\hline Early GC & $13(9 \%)$ \\
\hline Advanced GC & $47(34 \%)$ \\
\hline GC (unspecified stage) & $78(57 \%)$ \\
\hline \multicolumn{2}{|l|}{ Intervention used } \\
\hline Intracorporeal oesophagojejunostomy & $1(1 \%)$ \\
\hline Vagus nerve-preservation & $2(1 \%)$ \\
\hline Robotic gastrectomy & $16(12 \%)$ \\
\hline Laparoscopic gastrectomy & $43(31 \%)$ \\
\hline HIPEC & $19(14 \%)$ \\
\hline Endoscopic submucosal dissection & $1(1 \%)$ \\
\hline Carbon nanoparticles & $1(1 \%)$ \\
\hline Standardised $400 \mathrm{kcal}$ meal & $1(1 \%)$ \\
\hline Double tract reconstruction & $1(1 \%)$ \\
\hline Enhanced recovery after surgery programme & $5(4 \% 0$ \\
\hline Ultrasonic activated shears (UAS) & $2(1 \%)$ \\
\hline Open gastrectomy & $8(6 \%)$ \\
\hline Billroth reconstruction & $6(4 \%)$ \\
\hline Perianastomotic drain & $4(3 \%)$ \\
\hline Lymphadenectomy & $9(7 \%)$ \\
\hline Application of third space & $1(1 \%)$ \\
\hline Prophylactic cholecystectomy & $1(1 \%)$ \\
\hline Nasogastric decompression & $1(1 \%)$ \\
\hline Spleen-preservation & $2(1 \%)$ \\
\hline Laparoscopic enforced sutures & $1(1 \%)$ \\
\hline Adjuvant chemotherapy & $6(4 \%)$ \\
\hline Neoadjuvant chemotherapy & $3(2 \%)$ \\
\hline Roux-en-Y reconstruction & $2(1 \%)$ \\
\hline Perioperative electropuncture & $1(1 \%)$ \\
\hline Total omentectomy & $1(1 \%)$ \\
\hline
\end{tabular}


Table 4. Clinical findings of interventional clinical trials involving gastrectomy for GC.

\begin{tabular}{|c|c|c|c|c|c|c|c|}
\hline Authors & Year & Trial & NCTID & $\begin{array}{l}\text { Number } \\
\text { enrolled }\end{array}$ & $\begin{array}{l}\text { Inclusion } \\
\text { criteria }\end{array}$ & $\begin{array}{l}\text { Primary } \\
\text { outcome }\end{array}$ & Result \\
\hline $\begin{array}{l}\text { Sakuramoto et } \\
\text { al [30] }\end{array}$ & 2007 & $\begin{array}{l}\text { Adjuvant chemotherapy for } \\
\text { gastric cancer with S-1, an } \\
\text { oral fluoropyrimidine }\end{array}$ & NCT00152217 & 529 & LAGC & Overall survival & $\begin{array}{l}\text { Oral fluoropyrimidine is an } \\
\text { effective adjuvant treatment } \\
\text { for LAGC }\end{array}$ \\
\hline $\begin{array}{l}\text { Nakajima et al } \\
\text { [31] }\end{array}$ & 2007 & $\begin{array}{l}\text { Randomized controlled trial } \\
\text { of adjuvant uracil-tegafur } \\
\text { versus surgery alone for } \\
\text { serosa-negative, locally } \\
\text { advanced gastric cancer }\end{array}$ & NCT00152243 & 190 & $\begin{array}{l}\text { Seronegative, } \\
\text { node positive } \\
\text { GC }\end{array}$ & Overall survival & $\begin{array}{l}\text { Significant survival benefit } \\
\text { for postoperative adjuvant } \\
\text { chemotherapy with uracil- } \\
\text { tegafur }\end{array}$ \\
\hline $\begin{array}{l}\text { Sasako et al } \\
\text { [32] }\end{array}$ & 2008 & $\begin{array}{l}\text { D2 lymphadenectomy alone } \\
\text { or with para-aortic nodal } \\
\text { dissection for gastric cancer }\end{array}$ & NCT00149279 & 523 & GC & Overall survival & $\begin{array}{l}\text { Treatment with } \mathrm{D} 2 \\
\text { lymphadenectomy plus para- } \\
\text { aortic nodal dissection does } \\
\text { not improve the survival rate }\end{array}$ \\
\hline $\begin{array}{l}\text { Iwahashi et al } \\
\text { [27] }\end{array}$ & 2009 & $\begin{array}{l}\text { Evaluation of double tract } \\
\text { reconstruction after total } \\
\text { gastrectomy in patients with } \\
\text { gastric cancer: prospective } \\
\text { randomized controlled trial }\end{array}$ & NCT00746161 & 44 & GC & Quality of life & $\begin{array}{l}\text { No difference between } \\
\text { double tract and Roux-En-Y } \\
\text { for total gastrectomy }\end{array}$ \\
\hline $\begin{array}{l}\text { Miyashiro et al } \\
\text { [33] }\end{array}$ & 2011 & $\begin{array}{l}\text { Randomized clinical trial } \\
\text { of adjuvant chemotherapy } \\
\text { with intraperitoneal and } \\
\text { intravenous cisplatin followed } \\
\text { by oral fluorouracil (UFT) in } \\
\text { serosa-positive gastric cancer } \\
\text { versus curative resection } \\
\text { alone: final results of the } \\
\text { Japan Clinical Oncology } \\
\text { Group trial JCOG9206-2 }\end{array}$ & NCT00147147 & 268 & GC & Overall survival & $\begin{array}{l}\text { No benefit in overall and } \\
\text { relapse-free survival with } \\
\text { intraperitoneal cisplatin, } \\
\text { postoperative intravenous } \\
\text { cisplatin and 5-FU }\end{array}$ \\
\hline Kim et al [26] & 2013 & $\begin{array}{l}\text { Long-term outcomes of } \\
\text { laparoscopy-assisted distal } \\
\text { gastrectomy for early } \\
\text { gastric cancer: result of a } \\
\text { randomized controlled trial } \\
\text { (COACT 0301) }\end{array}$ & NCT00546468 & 164 & Early distal GC & 5-year DFS & $\begin{array}{l}\text { No difference in long- } \\
\text { term benefits between } \\
\text { laparoscopic distal } \\
\text { gastrectomy (LDG) and open } \\
\text { distal gastrectomy (ODG) }\end{array}$ \\
\hline Lee et al [34] & 2013 & $\begin{array}{l}\text { Morbidity and mortality after } \\
\text { laparoscopic gastrectomy } \\
\text { for advanced gastric cancer: } \\
\text { results of a phase II clinical } \\
\text { trial }\end{array}$ & NCT01441336 & 204 & LAGC & $\begin{array}{l}\text { Feasibility of } \\
\text { laparoscopic } \\
\text { gastrectomy }\end{array}$ & $\begin{array}{l}\text { LG with D2 } \\
\text { lymphadenectomy is safe } \\
\text { and feasible }\end{array}$ \\
\hline $\begin{array}{l}\text { Bernini et al } \\
\text { [35] }\end{array}$ & 2013 & $\begin{array}{l}\text { The Cholegas Study: safety of } \\
\text { prophylactic cholecystectomy } \\
\text { during gastrectomy for } \\
\text { cancer: preliminary results } \\
\text { of a multicentric randomized } \\
\text { clinical trial }\end{array}$ & NCT00757640 & 172 & GC & $\begin{array}{l}\text { Evaluation of } \\
\text { the incidence } \\
\text { of cholelithiasis } \\
\text { postoperatively }\end{array}$ & $\begin{array}{l}\text { Concomitant } \\
\text { cholecystectomy adds } \\
\text { no extra perioperative } \\
\text { morbidity, mortality and } \\
\text { costs }\end{array}$ \\
\hline
\end{tabular}


Table 4. Clinical findings of interventional clinical trials involving gastrectomy for GC. (Continued)

\begin{tabular}{|c|c|c|c|c|c|c|c|}
\hline $\begin{array}{l}\text { Haverkamp et } \\
\text { al [5] }\end{array}$ & 2015 & $\begin{array}{l}\text { Laparoscopic versus open } \\
\text { gastrectomy for gastric } \\
\text { cancer, a multicenter } \\
\text { prospectively randomized } \\
\text { controlled trial (LOGICA-trial) }\end{array}$ & NCT02248519 & 210 & $\begin{array}{l}\text { Surgically } \\
\text { resectable GC }\end{array}$ & $\begin{array}{l}\text { Postoperative } \\
\text { hospital stay }\end{array}$ & $\begin{array}{l}\text { Laparoscopic surgery } \\
\text { provides shorter hospital } \\
\text { stay }\end{array}$ \\
\hline $\begin{array}{l}\text { Abdikarim et al } \\
\text { [36] }\end{array}$ & 2015 & $\begin{array}{l}\text { Enhanced recovery after } \\
\text { surgery with laparoscopic } \\
\text { radical gastrectomy for } \\
\text { stomach carcinomas }\end{array}$ & NCT01955096 & 61 & GC & $\begin{array}{l}\text { Postoperative } \\
\text { hospital stay }\end{array}$ & $\begin{array}{l}\text { ERAS programme is } \\
\text { associated with shorter } \\
\text { hospital stay }\end{array}$ \\
\hline $\begin{array}{l}\text { Nakamura et al } \\
\text { [37] }\end{array}$ & 2016 & $\begin{array}{l}\text { Randomized clinical trial } \\
\text { comparing long-term quality } \\
\text { of life for Billroth I versus } \\
\text { Roux-en-Y reconstruction } \\
\text { after distal gastrectomy for } \\
\text { gastric cancer }\end{array}$ & NCT01065688 & 122 & GC & Quality of life & $\begin{array}{l}\text { No difference between } \\
\text { Billroth I and Roux-en-Y } \\
\text { reconstruction }\end{array}$ \\
\hline Oh et al [38] & 2017 & $\begin{array}{l}\text { Ultrasonically Activated } \\
\text { Shears Reduce Blood } \\
\text { Loss without Increasing } \\
\text { Inflammatory Reactions in } \\
\text { Open Distal Gastrectomy } \\
\text { for Cancer: A Randomized } \\
\text { Controlled Study }\end{array}$ & NCT01971775 & 56 & GC & $\begin{array}{l}\text { Estimated } \\
\text { blood loss } \\
\text { (EBL) during } \\
\text { surgery }\end{array}$ & $\begin{array}{l}\text { UAS reduced EBL without } \\
\text { increasing inflammatory } \\
\text { reactions }\end{array}$ \\
\hline Lee et al [39] & 2017 & $\begin{array}{l}\text { Safety and feasibility of } \\
\text { reduced-port robotic distal } \\
\text { gastrectomy for gastric } \\
\text { cancer: a phase I/II clinical } \\
\text { trial }\end{array}$ & NCT02347956 & 40 & Early GC & $\begin{array}{l}30 \text {-day } \\
\text { morbidity and } \\
\text { mortality }\end{array}$ & $\begin{array}{l}\text { Reduced-port robotic distal } \\
\text { gastrectomy could be a valid } \\
\text { alternative to conventional } \\
\text { robot distal gastrectomy }\end{array}$ \\
\hline Park et al [40] & 2018 & $\begin{array}{l}\text { Laparoscopy-Assisted versus } \\
\text { Open D2 Distal Gastrectomy } \\
\text { for Advanced Gastric Cancer: } \\
\text { Results From a Randomized } \\
\text { Phase II Multicenter Clinical } \\
\text { Trial (COACT 1001) }\end{array}$ & NCT01088204 & 204 & LAGC & $\begin{array}{l}\text { Noncompliance } \\
\text { rate of lymph } \\
\text { node dissection }\end{array}$ & $\begin{array}{l}\text { LDG is feasible for D2 lymph } \\
\text { node dissection }\end{array}$ \\
\hline Kang et al [41] & 2018 & $\begin{array}{l}\text { Multimodal Enhanced } \\
\text { Recovery After Surgery } \\
\text { (ERAS) Program is the } \\
\text { Optimal Perioperative Care } \\
\text { in Patients Undergoing } \\
\text { Totally Laparoscopic Distal } \\
\text { Gastrectomy for Gastric } \\
\text { Cancer: A Prospective, } \\
\text { Randomized, Clinical Trial }\end{array}$ & NCT01938313 & 97 & GC & Recovery time & $\begin{array}{l}\text { ERAS is safe and enhances } \\
\text { postoperative recovery after } \\
\text { total laparoscopic distal } \\
\text { gastrectomy in GC }\end{array}$ \\
\hline Zheng et al [42] & 2018 & $\begin{array}{l}\text { Comparison of 3D } \\
\text { laparoscopic gastrectomy } \\
\text { with a } 2 \mathrm{D} \text { procedure for } \\
\text { gastric cancer: A phase } 3 \\
\text { randomized controlled trial }\end{array}$ & NCT02327481 & 438 & GC & $\begin{array}{l}\text { Short-term } \\
\text { postoperative } \\
\text { complications } \\
\text { and mortality }\end{array}$ & $\begin{array}{l}\text { 3D laparoscopic gastrectomy } \\
\text { does not shorten the } \\
\text { operation time compared } \\
\text { with 2D laparoscopic } \\
\text { gastrectomy, but provides } \\
\text { less intraoperative blood loss } \\
\text { and a lesser occurrence of } \\
\text { excessive bleeding }\end{array}$ \\
\hline
\end{tabular}


Table 4. Clinical findings of interventional clinical trials involving gastrectomy for GC. (Continued)

\begin{tabular}{|c|c|c|c|c|c|c|c|}
\hline Li et al [43] & 2019 & $\begin{array}{l}\text { Assessment of Laparoscopic } \\
\text { Distal Gastrectomy After } \\
\text { Neoadjuvant Chemotherapy } \\
\text { for Locally Advanced Gastric } \\
\text { Cancer: A Randomized } \\
\text { Clinical Trial }\end{array}$ & NCT02404753 & 96 & $\begin{array}{l}\text { LAGC } \\
\text { receiving } \\
\text { neoadjuvant } \\
\text { therapy }\end{array}$ & $\begin{array}{l}\text { 3-year } \\
\text { recurrence free } \\
\text { survival }\end{array}$ & $\begin{array}{l}\text { LDG provides better } \\
\text { outcomes than the ODG } \\
\text { approach }\end{array}$ \\
\hline Ahn et al [44] & 2019 & $\begin{array}{l}\text { Long-term Survival Outcomes } \\
\text { of Laparoscopic Gastrectomy } \\
\text { for Advanced Gastric Cancer: } \\
\text { Five-year Results of a Phase } \\
\text { II Prospective Clinical Trial }\end{array}$ & NCT01441336 & 157 & LAGC & $\begin{array}{l}\text { 3-year } \\
\text { recurrence free } \\
\text { survival }\end{array}$ & $\begin{array}{l}\text { Laparoscopic gastrectomy } \\
\text { with D2 lymphadenectomy } \\
\text { shows acceptable 3-year } \\
\text { DFS }\end{array}$ \\
\hline Yu et al [45] & 2019 & $\begin{array}{l}\text { Effect of Laparoscopic vs } \\
\text { Open Distal Gastrectomy on } \\
\text { 3-Year Disease-Free Survival } \\
\text { in Patients With Locally } \\
\text { Advanced Gastric Cancer: } \\
\text { The CLASS-01 Randomized } \\
\text { Clinical Trial }\end{array}$ & NCT01609309 & 1056 & LAGC & $\begin{array}{l}\text { 3-year } \\
\text { recurrence free } \\
\text { survival }\end{array}$ & $\begin{array}{l}\text { LDG is not significantly } \\
\text { superior to ODG }\end{array}$ \\
\hline Kim et al [46] & 2019 & $\begin{array}{l}\text { Effect of Laparoscopic Distal } \\
\text { Gastrectomy vs Open Distal } \\
\text { Gastrectomy on Long-term } \\
\text { Survival Among Patients } \\
\text { With Stage I Gastric Cancer: } \\
\text { The KLASS-01 Randomized } \\
\text { Clinical Trial }\end{array}$ & NCT00452751 & 1416 & Stage I GC & 5-year DFS & $\begin{array}{l}\text { LDG is a safe alternative to } \\
\text { ODG for stage I GC }\end{array}$ \\
\hline Guo et al [47] & 2019 & $\begin{array}{l}\text { Combined Surgery and } \\
\text { Extensive Intraoperative } \\
\text { Peritoneal Lavage vs Surgery } \\
\text { Alone for Treatment of } \\
\text { Locally Advanced Gastric } \\
\text { Cancer: The SEIPLUS } \\
\text { Randomized Clinical Trial }\end{array}$ & NCT02745509 & 662 & LAGC & $\begin{array}{l}\text { Short-term } \\
\text { postoperative } \\
\text { complications } \\
\text { and mortality }\end{array}$ & $\begin{array}{l}\text { Patients with LAGC appear } \\
\text { to be candidates for the } \\
\text { extensive intraoperative } \\
\text { peritoneal lavage approach }\end{array}$ \\
\hline Wang et al [48] & 2019 & $\begin{array}{l}\text { Short-term surgical outcomes } \\
\text { of laparoscopy-assisted } \\
\text { versus open D2 distal } \\
\text { gastrectomy for locally } \\
\text { advanced gastric cancer in } \\
\text { North China: a multicenter } \\
\text { randomized controlled trial }\end{array}$ & NCT02464215 & 446 & LAGC & $\begin{array}{l}\text { Morbidity } \\
\text { and mortality } \\
\text { within } 30 \\
\text { postoperative } \\
\text { days }\end{array}$ & $\begin{array}{l}\text { LDG was safe and feasible } \\
\text { compared with conventional } \\
\text { ODG }\end{array}$ \\
\hline Chen et al [49] & 2020 & $\begin{array}{l}\text { Safety and Efficacy } \\
\text { of Indocyanine Green } \\
\text { Tracer-Guided Lymph } \\
\text { Node Dissection During } \\
\text { Laparoscopic Radical } \\
\text { Gastrectomy in Patients } \\
\text { With Gastric Cancer: A } \\
\text { Randomized Clinical Trial }\end{array}$ & NCT03050879 & 266 & $\begin{array}{l}\text { Potentially } \\
\text { resectable GC }\end{array}$ & $\begin{array}{l}\text { Number of } \\
\text { retrieved lymph } \\
\text { nodes }\end{array}$ & $\begin{array}{l}\text { Indocyanine green improve } \\
\text { the number of lymph node } \\
\text { dissections and reduce } \\
\text { lymph node noncompliance } \\
\text { without increased } \\
\text { complications }\end{array}$ \\
\hline
\end{tabular}


On average, the length of trials in this work was 3.9 years. It may be hypothesised that the long lengths of trials are owed to schemas of the respective studies. In addition, obligatory approvals and financial/logistical backing often taken a lot of time. With better planning and optimised time managing, the lengths of studies may become shorter. This would result in faster development of new gastrectomy surgical management plans for GC. Introducing 'new master protocols' for the screening of patients in regard to numerous features such as race and ethnicity, genetic profile and sex could help in restructuring selection processes and in the assignment of volunteers into trials in a well-matched manner according to their profile [18]. The termination of most trials was in fact due to the slow or poor participation of patients, and discontinuation of funding. The recruitment for clinical trials has been inept to increase the number of participants [19]. Health communication strategies using advertisement and media outlets did not succeed in expanding the overall volunteer number until now [20]. However, the optimal use of electronic health records (EHR) in screening for potential candidates has proved to improve volunteer requirement into trials [21]. The recruitment of participants to gastrectomy clinical trials for GC may become more effective and quicker now that a growing number of medical centres and institutions have started to adopt EHR systems. Also, surgeons that treat patients with GC are required to stay up to date on the current gastrectomy clinical trials in order to advise said patients to volunteer in them. Previous reports shown that people are more prone to volunteer in clinical trials if their primary care physician recommends it [22]. Decreased funding has led to a substantial decrease in the number of new clinical trials and increase in the number of terminated ones [23]. Reasons such as increase in trial cost and presence of constant budgets with price inflations have caused the decreased funding of interventional clinical trials [23]. These factors can help in decreasing design and recruitment duration, prevent termination of trials and generate more viable results with larger sample sizes.

Of the 138 trials included in our study, 57 publications attributed to 39 clinical trials have been produced. This amounts to a $28 \%$ publishing rate from clinical trials involving gastrectomy for GC. Several reasons may explain this low figure. Since significant time and efforts are put into designing, setting up, conducting and analysing results of clinical trials, it may be thought that taking the decision of not publishing one made by the investigator(s) or sponsor of study. Such decisions might be taken due to discrepancies in desired versus observed results [24]. Another factor would be the decision of non-publishing bias of negative results, a phenomena that has already made its way into many clinical trials [24]. However, publishing of negative results may help other researchers in focusing future research efforts by informing others of the potential difficulties and obstacles faced during any respective trial. Publishing of said negative results could help surgeons in avoiding repetition of failing gastrectomy/gastrectomy related plans and thus divert efforts to other possible new interventions.

\section{Treated topics}

The most commonly treated topics in our evaluated studies were on nonspecific GC, locally advanced gastric cancer (LAGC) and early-stage GC. This is because patients with these tumours are free from any contraindications of gastric surgery. The commonly used procedures are shown in Figure 3. The most common contraindications for gastric resection include patients being unfit for general anaesthesia and those who have extremely poor prognosis (distant metastasis) [25]. As such, clinical trials involving gastrectomy can be for these malignancies. The most commonly studied primary outcomes involved overall survival and 3-year disease-free survival (DFS) in published works from the clinical trials. Studies showed for the most commonly treated topics that different surgical approaches show no significant difference in terms of long-term survival but do help in immediate postoperative course [26, 27]. Current research lines are mainly focused on procedures including laparoscopy, HIPEC and robotic-assisted operations. This is because of the trend of utilising more and more minimally invasive procedures such as laparoscopy and robotic techniques for their better post-operative outcomes as compared to open approaches [28]. The increased use of HIPEC has also been reported in other cancers such as ovarian cancer, explaining the trend for increased trials in GC [29]. More clinical trials and publications must be produced on the common treated topics of GC (early stage and local advancement with no metastasis) to investigate ways which improve long-term outcomes. Better publishing of the current research lines and techniques being utilised is important to know their clinical outcomes.

\section{Limitations}

The focus of this study is primarily on trials involving gastrectomy for patients with GC only. The strength of the results generated depends on the accuracy of the information from the source database ('ClinicalTrials.gov'). Our study utilises the ClinicalTrials.gov database alone. The use of other databases such as the WHO International Clinical Trials Registry Platform or Cochrane database for clinical trials could have generated possibly more clinical trials. Inaccuracies might have been present in the trial data such as whether the data is up-to-date or not. Other issues could have been that data might be missing altogether from the registry. 

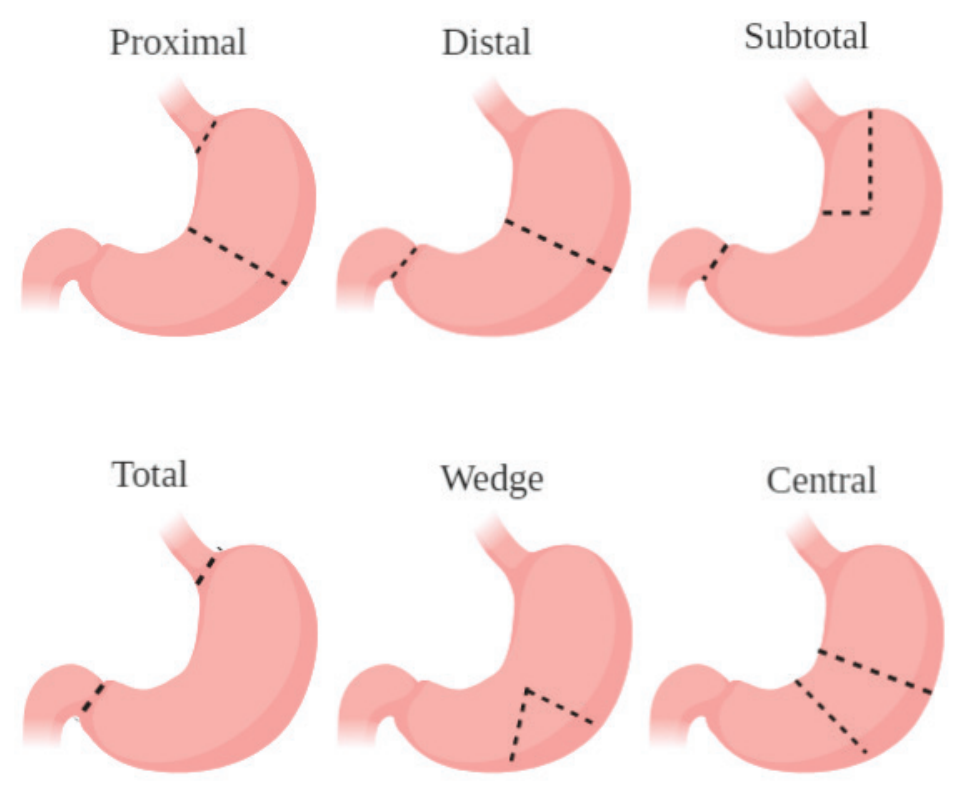

Figure 3. Illustration of the most common types of gastrectomies performed for GC.

\section{Conclusion}

Clinical trials involving gastrectomy for GC have a small number, minimal publishing rate and lack of geographic variety. Laparoscopy is the most common intervention being studied in clinical trials involving gastrectomy. Increased research efforts, funding and proper management are needed to improve and expand clinical trials, which in turn will improve patient outcomes.

\section{List of abbreviations}

ERAS, Enhanced recovery after surgery; LAGC, Locally advanced gastric cancer; UAS, Ultrasonically activated shears; EBL, Estimated blood loss; LDG, Laparoscopic distal gastrectomy; ODG, Open distal gastrectomy; DFS, Disease-free survival.

\section{Funding}

The authors declare that this study did not receive any funding.

\section{Conflicts of interest}

The authors declare no conflict of interest. 


\section{Compliance with ethical standards}

The authors declare no conflict of interest. This study did not include any research involving human participants and/or animal subjects.

\section{Authors' contributions}

H.H.K and M.A.C were responsible for the concept and design of the study; H.H.K and H.A.S for data acquisition; H.H.K and M.Y.F for statistical analysis; H.H.K, H.A.S, M.Y.F and F.R.J interpreted the results; H.H.K, M.A.C and F.R.J analysed the data and drafted the manuscript. All authors critically revised the manuscript, approved the final version to be published and agree to be accountable for all aspects of the work.

\section{References}

1. Khachfe HH, Salhab HA, and Fares MY, et al (2020) Probing the colorectal cancer incidence in Lebanon: an 11-year epidemiological study J Gastrointest Cancer 51(3) 805-812 https://doi.org/10.1007/s12029-019-00284-z

2. Bray F, Ferlay J, and Soerjomataram I, et al (2018) Global cancer statistics 2018: GLOBOCAN estimates of incidence and mortality worldwide for 36 cancers in 185 countries CA Cancer J Clin 68(6) 394-424 https://doi.org/10.3322/caac.21492 PMID: 30207593

3. Karimi P, Islami F, and Anandasabapathy S, et al (2014) Gastric cancer: descriptive epidemiology, risk factors, screening, and prevention Cancer Epidemiol Biomarkers Prev 23(5) 700-713 https://doi.org/10.1158/1055-9965.EPI-13-1057 PMID: 24618998 PMCID: 4019373

4. Forman D and Burley VJ (2006) Gastric cancer: global pattern of the disease and an overview of environmental risk factors Best Pract Res Clin Gastroenterol 20(4) 633-649 https://doi.org/10.1016/j.bpg.2006.04.008 PMID: 16997150

5. Haverkamp L, Brenkman HJF, and Seesing MFJ, et al (2015) Laparoscopic versus open gastrectomy for gastric cancer, a multicenter prospectively randomized controlled trial (LOGICA-trial) BMC Cancer 15556 https://doi.org/10.1186/s12885-015-1551-z PMID: 26219670 PMCID: 4518687

6. Cunningham D, Allum WH, and Stenning SP, et al (2006) Perioperative chemotherapy versus surgery alone for resectable gastroesophageal cancer N Engl J Med 355(1) 11-20 https://doi.org/10.1056/NEJMoa055531 PMID: 16822992

7. Hartgrink $\mathrm{HH}$, van de Velde $\mathrm{CJ}$, and Putter $\mathrm{H}$, et al (2004) Extended lymph node dissection for gastric cancer: who may benefit? Final results of the randomized Dutch gastric cancer group trial J Clin Oncol 22(11) 2069-2077 https://doi.org/10.1200/JCO.2004.08.026 PMID: 15082726

8. Hur H, Lee HY, and Lee H-J, et al (2015) Efficacy of laparoscopic subtotal gastrectomy with D2 lymphadenectomy for locally advanced gastric cancer: the protocol of the KLASS-02 multicenter randomized controlled clinical trial BMC Cancer 15355 https://doi. org/10.1186/s12885-015-1365-z PMID: 25939684 PMCID: 4432816

9. Jeong SH, Lee YJ, and Park ST, et al (2011) Risk of recurrence after laparoscopy-assisted radical gastrectomy for gastric cancer performed by a single surgeon Surg Endosc 25(3) 872-878 https://doi.org/10.1007/s00464-010-1286-5

10. Kim YW, Baik YH, and Yun YH, et al (2008) Improved quality of life outcomes after laparoscopy-assisted distal gastrectomy for early gastric cancer: results of a prospective randomized clinical trial Ann Surg 248(5) 721-727 https://doi.org/10.1097/SLA.0b013e318185e62e PMID: 18948798

11. Siddaiah-Subramanya M, Tiang KW, and Nyandowe $M$ (2017) A new era of minimally invasive surgery: progress and development of major technical innovations in general surgery over the last decade Surg J (N Y) 3(4) e163-e166 https://doi.org/10.1055/s-0037-1608651 
12. Khachfe HH, Salhab HA, and Fares MY, et al (2019) Current state of hypertrophic cardiomyopathy clinical trials Global Heart 14(3) 317-325 https://doi.org/10.1016/j.gheart.2019.07.005 PMID: 31451240

13. Fares J, Kanojia D, and Rashidi A, et al (2020) Landscape of combination therapy trials in breast cancer brain metastasis Int J Cancer https://doi.org/10.1002/ijc.32937 PMID: 32086955 PMCID: 7423704

14. Nasrallah AA, Khachfe HH, and Salhab HA, et al (2020) Targeted therapies in trial for non-resectable gallbladder cancer J Gastrointest Cancer https://doi.org/10.1007/s12029-020-00411-1 PMID: 32394022

15. FDA Food and Drug Administration Amendments Act of 20072007

16. Kammen DM and Kirubi C (2008) Poverty, energy, and resource use in developing countries: focus on Africa Ann N Y Acad Sci 1136 348-357 https://doi.org/10.1196/annals.1425.030 PMID: 18579892

17. Jemal A, Center MM, and DeSantis C, et al (2010) Global patterns of cancer incidence and mortality rates and trends Cancer Epidemiol Biomarkers Prev 19(8) 1893-1907 https://doi.org/10.1158/1055-9965.EPI-10-0437 PMID: 20647400

18. Woodcock J and LaVange LM (2017) Master protocols to study multiple therapies, multiple diseases, or both N Engl J Med 377(1) 62-70 https://doi.org/10.1056/NEJMra1510062 PMID: 28679092

19. Reynolds T (2011) Clinical trials: can technology solve the problem of low recruitment? BMJ 342 d3662 https://doi.org/10.1136/bmj. d3662 PMID: 21672994

20. Unger JM, Cook E, and Tai E, et al (2016) The role of clinical trial participation in cancer research: barriers, evidence, and strategies Am Soc Clin Oncol Educ Book 35 185-198 https://doi.org/10.1200/EDBK_156686 PMID: 27249699 PMCID: 5495113

21. Embi PJ, Jain A, and Clark J, et al (2005) Effect of a clinical trial alert system on physician participation in trial recruitment Arch Intern Med 165(19) 2272-2277 https://doi.org/10.1001/archinte.165.19.2272 PMID: 16246994 PMCID: 1343501

22. Siminoff LA, Zhang A, and Colabianchi N, et al (2000) Factors that predict the referral of breast cancer patients onto clinical trials by their surgeons and medical oncologists J Clin Oncol 18(6) 1203-1211 https://doi.org/10.1200/JCO.2000.18.6.1203 PMID: 10715289

23. Gresham GK, Ehrhardt S, and Meinert JL, et al (2018) Characteristics and trends of clinical trials funded by the National Institutes of Health between 2005 and 2015 Clin Trials 15(1) 65-74 https://doi.org/10.1177/1740774517727742 PMCID: 5802548

24. Jones CW, Handler L, and Crowell KE, et al (2013) Non-publication of large randomized clinical trials: cross sectional analysis BMJ 347 f6104 https://doi.org/10.1136/bmj.f6104 PMID: 24169943 PMCID: 3812466

25. Marsh AMBJ (2020) Gastric Resection (Treasure Island: StatPearls Publishing) [https://www.ncbi.nlm.nih.gov/books/NBK560760/] Date accessed: 19/03/21

26. Kim YW, Yoon HM, and Yun YH, et al (2013) Long-term outcomes of laparoscopy-assisted distal gastrectomy for early gastric cancer: result of a randomized controlled trial (COACT 0301) Surg Endosc 27(11) 4267-4276 https://doi.org/10.1007/s00464-013-3037-x PMID: 23793805

27. Iwahashi M, Nakamori M, and Nakamura M, et al (2009) Evaluation of double tract reconstruction after total gastrectomy in patients with gastric cancer: prospective randomized controlled trial World J Surg 33(9) 1882-1888 https://doi.org/10.1007/s00268-0090109-0 PMID: 19548028

28. Zureikat AH, Moser AJ, and Boone BA, et al (2013) 250 robotic pancreatic resections: safety and feasibility Ann Surg 258(4) 554-562 https://doi.org/10.1097/SLA.0b013e3182a4e87c PMID: 24002300 PMCID: 4619895

29. Charo LM, Jou J, and Binder P, et al (2020) Current status of hyperthermic intraperitoneal chemotherapy (HIPEC) for ovarian cancer in the United States Gynecol Oncol 159(3) 681-686 https://doi.org/10.1016/j.ygyno.2020.09.022 PMID: 32977989 
30. Sakuramoto S, Sasako M, and Yamaguchi T, et al (2007) Adjuvant chemotherapy for gastric cancer with S-1, an oral fluoropyrimidine $N$ Engl J Med 357(18) 1810-1820 https://doi.org/10.1056/NEJMoa072252 PMID: 17978289

31. Nakajima T, Kinoshita T, and Nashimoto A, et al (2007) Randomized controlled trial of adjuvant uracil-tegafur versus surgery alone for serosa-negative, locally advanced gastric cancer Br J Surg 94 (12) 1468-1476 https://doi.org/10.1002/bjs.5996 PMID: 17948223

32. Sasako M, Sano T, and Yamamoto $S$, et al (2008) D2 lymphadenectomy alone or with para-aortic nodal dissection for gastric cancer $N$ Engl J Med 359(5) 453-462 https://doi.org/10.1056/NEJMoa0707035 PMID: 18669424

33. Miyashiro I, Furukawa H, and Sasako M, et al (2011) Randomized clinical trial of adjuvant chemotherapy with intraperitoneal and intravenous cisplatin followed by oral fluorouracil (UFT) in serosa-positive gastric cancer versus curative resection alone: final results of the Japan Clinical Oncology Group trial JCOG9206-2 Gastric Cancer 14(3) 212-218 https://doi.org/10.1007/s10120-011-0027-3 PMID: $\underline{21336855}$

34. Lee JH, Son SY, and Lee CM, et al (2013) Morbidity and mortality after laparoscopic gastrectomy for advanced gastric cancer: results of a phase II clinical trial Surg Endosc 27(8) 2877-2885 https://doi.org/10.1007/s00464-013-2848-0 PMID: 23404155

35. Bernini M, Bencini L, and Sacchetti R, et al (2013) The Cholegas Study: safety of prophylactic cholecystectomy during gastrectomy for cancer: preliminary results of a multicentric randomized clinical trial Gastric Cancer 16(3) 370-376 https://doi.org/10.1007/s10120$\underline{012-0195-9}$

36. Abdikarim I, Cao XY, and Li SZ, et al (2015) Enhanced recovery after surgery with laparoscopic radical gastrectomy for stomach carcinomas World J Gastroenterol 21(47) 13339-13344 https://doi.org/10.3748/wjg.v21.i47.13339 PMID: 26715818 PMCID: 4679767

37. Nakamura M, Nakamori M, and Ojima T, et al (2016) Randomized clinical trial comparing long-term quality of life for Billroth I versus Roux-en-Y reconstruction after distal gastrectomy for gastric cancer Br J Surg 103(4) 337-347 https://doi.org/10.1002/bjs.10060 PMID: 26840944

38. Oh SY, Choi B, and Lee KG, et al (2017) Ultrasonically activated shears reduce blood loss without increasing inflammatory reactions in open distal gastrectomy for cancer: a randomized controlled study Ann Surg Oncol 24(2) 494-501 https://doi.org/10.1245/s10434016-5518-3

39. Lee S, Kim JK, and Kim YN, et al (2017) Safety and feasibility of reduced-port robotic distal gastrectomy for gastric cancer: a phase I/II clinical trial Surg Endosc 31(10) 4002-4009 https://doi.org/10.1007/s00464-017-5435-y PMID: 28205030

40. Park YK, Yoon HM, and Kim YW, et al (2018) Laparoscopy-assisted versus Open D2 distal gastrectomy for advanced gastric cancer: Results From a Randomized Phase II Multicenter Clinical Trial (COACT 1001) Ann Surg 267(4) 638-645 https://doi.org/10.1097/ SLA.0000000000002168

41. Kang SH, Lee Y, and Min SH, et al (2018) Multimodal enhanced recovery after surgery (eras) program is the optimal perioperative care in patients undergoing totally laparoscopic distal gastrectomy for gastric cancer: a prospective, randomized, clinical trial Ann Surg Oncol 25(11) 3231-3238 https://doi.org/10.1245/s10434-018-6625-0 PMID: 30051365

42. Zheng CH, Lu J, and Zheng HL, et al (2018) Comparison of 3D laparoscopic gastrectomy with a 2D procedure for gastric cancer: a phase 3 randomized controlled trial Surgery 163(2) 300-304 https://doi.org/10.1016/j.surg.2017.09.053

43. Li Z, Shan F, and Ying X, et al (2019) Assessment of laparoscopic distal gastrectomy after neoadjuvant chemotherapy for locally advanced gastric cancer: a randomized clinical trial JAMA Surg 154(12) 1093-1101 https://doi.org/10.1001/jamasurg.2019.3473 PMID: 31553463 PMCID: 6763995

44. Ahn SH, Kang SH, and Lee $\mathrm{Y}$, et al (2019) Long-term survival outcomes of laparoscopic gastrectomy for advanced gastric cancer: five-year results of a phase ii prospective clinical trial J Gastric Cancer 19(1) 102-110 https://doi.org/10.5230/jgc.2019.19.e6 PMID: 30944763 PMCID: 6441772 
45. Yu J, Huang C, and Sun Y, et al (2019) Effect of laparoscopic vs open distal gastrectomy on 3-year disease-free survival in patients with locally advanced gastric cancer: The CLASS-01 randomized clinical trial JAMA 321(20) 1983-1992 https://doi.org/10.1001/ jama.2019.5359 PMID: 31135850 PMCID: 6547120

46. Kim HH, Han SU, and Kim MC, et al (2019) Effect of laparoscopic distal gastrectomy vs open distal gastrectomy on long-term survival among patients with stage I gastric cancer: the KLASS-01 randomized clinical trial JAMA Oncol 5(4) 506-513 https://doi.org/10.1001/ jamaoncol.2018.6727 PMID: 30730546 PMCID: 6459124

47. Guo J, Xu A, and Sun X, et al (2019) Combined surgery and extensive intraoperative peritoneal lavage vs surgery alone for treatment of locally advanced gastric cancer: the SEIPLUS randomized clinical trial JAMA Surg 154(7) 610-616 https://doi.org/10.1001/jamasurg.2019.0153 PMID: 30916742 PMCID: 6583840

48. Wang Z, Xing J, and Cai J, et al (2019) Short-term surgical outcomes of laparoscopy-assisted versus open D2 distal gastrectomy for locally advanced gastric cancer in North China: a multicenter randomized controlled trial Surg Endosc 33(1) 33-45 https://doi. org/10.1007/s00464-018-6391-x PMCID: 6336741

49. Chen QY, Xie JW, and Zhong Q, et al (2020) Safety and efficacy of indocyanine green tracer-guided lymph node dissection during laparoscopic radical gastrectomy in patients with gastric cancer: a randomized clinical trial JAMA Surg 155(4) 300-311 https://doi. org/10.1001/jamasurg.2019.6033 PMID: 32101269 